\title{
Preliminary Design Procedure For ONE SPAN POST-TENSIONED STRESS-RIBBON BRIDGE
}

\author{
KALAFATIC, I.; RADIC, J. \& MEDAK, M.
}

Abstract: Stress-ribbon bridges are very slender structures used mainly for pedestrian and cycling traffic. Nowadays most deck slabs on stress-ribbon bridges are made of precast concrete segments eliminating usage of scaffolding and reducing cost of human labour. Main building components of bridge deck are bearing cables, concrete plate segments and cables for additional prestressing. Simplified design procedure for one span stress-ribbon bridge defined in Japanese Standards for Design of Stress-Ribbon Bridges is based on theory developed by prof. Eibl (Eibl et al., 1973.) He neglected different heights of bridge abutments and real length of bridge deck. This paper describes preliminary static design procedure for one span post-tensioned stress-ribbon bridge taking into account real length of structure and different heights of abutments. Main goal of defined procedure is to achieve desired shape of bridge deck under dead load and to optimize the number of bearing and post-tensioning cables.

Key words: Stress-ribbon bridge, preliminary design procedure, one span, posttensioning, static design
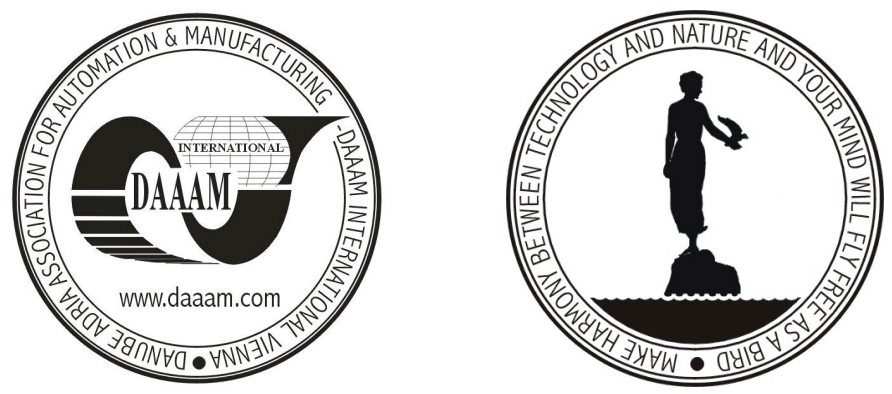

Authors' data: M.Sc.Civil Engineer Kalafatic I.[van]*, Professor PhD Radic J.[ure]**, Medak M.[atko]*, *Croatian Institute for Bridge and Structural Engineering, Croatia, **Faculty of Civil Engineering, University of Zagreb, Croatia, ivan.kalafatic@himk.hr,jradic@grad.hr,matko.medak@himk.hr

This Publication has to be referred as: Kalafatic, I.; Radic, J. \& Medak, M. (2006). Preliminary design procedure for one span post-tensioned stress-ribbon bridge, Chapter 25 in DAAAM International Scientific Book 2006, B. Katalinic (Ed.), Published by DAAAM International, ISBN 3-901509-47-X, ISSN 1726-9687, Vienna, Austria

DOI: $10.2507 /$ daaam.scibook.2006.25 